\title{
Virtual Prediction of Lycopene and Quercetin Effects on Angiogenesis Through VEGFR-2 Pathway
}

\author{
Rizky Senna Samoedra ${ }^{1 *}$, Fikriya Novita Sari ${ }^{1}$, Setyaki Kevin Pratama ${ }^{1}$ \\ ${ }^{1}$ Department of Biology, Faculty of Mathematics and Natural Science, Brawijaya University, Jalan Veteran, Malang, East Java, \\ Indonesia, 65145
}

Submission: June 2020; Revised: July 2020; Accepted: October 2020

*Corresponding author: Rizky Senna Samoedra; e-mail: risesamoedra@ gmail.com; tel.: +62-812-6411-8297

\begin{abstract}
Angiogenesis is a complex process that is required for cancer cells to perform metastasis. The binding of a growth factor such as VEGF to its receptor is a factor to trigger angiogenesis through the VEGFR-2 pathway. This study analyzed the effect of lycopene and quercetin from watermelon (Citrullus lanatus) on angiogenesis through VEGFR-2 pathway. The study was carried out in silico. Ligands were obtained from PubChem and prepared using PyRx, while the protein was obtained from PDB and prepared using BIOVIA Discovery Studio 2019. The docking was carried out by using HEX 8.0.0, and the results were visualized using BIOVIA Discovery Studio 2019. Lycopene and quercetin were able to bind with VEGFR-2 to interrupt the binding of VEGFA. The presence of lycopene and quercetin also lowers the binding strength of VEGFA with VEGFR-2 as they can affect interactions between VEGFA and $V E G F R-2$ at 4 and 5 amino acid residues by changing the type of interactions to make the binding strength weaker. The binding of lycopene and quercetin were potentially interrupted the downstream pathway of angiogenesis through the VEGFR-2 pathway.
\end{abstract}

Keywords: angiogenesis, cancer, lycopene, quercetin, VEGF-receptor2

\section{INTRODUCTION}

Cancer is one of the most dangerous chronic diseases in the world. It is a non-transmittable disease that is one of the main death cause in the world. Cancer patients increase 1,4 out of 1000 people in 2013 to 1,79 out of 1000 people in 2018 [1]. Cancer in Indonesia is placed eighth in southeast Asia, and it affects every people in the society. It does not discriminate whether the people suffer because it is old, young, or whether the gender is male or female [2].

Angiogenesis occurs when local endogenous chemical signals coordinate with endothelial cells and smooth muscles to repair damaged blood vessels or to produce new blood vessels. The angiogenesis process promotes cancer proliferation leading to the metastasis process [3]. Vascular endothelial growth factor (VEGF) is one of the growth factors used in angiogenesis. By binding with its receptor (VEGFR-1, VEGFR-2, VEGFR-3), VEGF stimulates the angiogenesis process utilized by cancer cells to spread to other tissues [4]. Suppressed of VEGFR pathway needs caused cancer cells not to spread to other tissues. The effect of angiogenesis from the VEGFR-2 pathway is much more significant than the VEGFR-1 and VEGFR-3 pathway. Therefore, angiogenesis inhibition is a more useful target for downregulating the VEGFR-2 pathway [5].

Lycopene and quercetin are found in watermelon (Citrullus lanatus) with the concentration are $144.27 \mathrm{mg} / \mathrm{kg}$ [6] and 4.69-
$171.27 \mu \mathrm{g} / \mathrm{g}$, respectively [7]. Both lycopene and quercetin have anti-inflammatory and antioxidant properties and can suppress VEGFR-2 protein expression [8]. These roles are essential to suppress cancer cell progression from preneoplastic to neoplastic and suppress cancer cell migration [9]. This research is conducted to analyze the effect of lycopene and quercetin on angiogenesis through the VEGFR-2 pathway.

\section{METHODS}

\section{Ligand Preparation}

Lycopene (CID: 446925) and quercetin (CID: 5280343) were obtained from PubChem database in SDF format. The energy of ligands was minimized and the file format was converted from SDF to PDB format by PyRx software [10].

\section{Protein Preparation}

The protein structure was obtained from Protein Data Bank as a VEGFR-2/VEGF-A complex (PDB ID: 3V2A). The protein was then prepared using BIOVIA Discovery Studio 2019 [11] to remove the ligands and water molecules.

\section{Docking and Visualization}

Docking was conducted by HEX 8.0.0 software [12] to predict the binding energy and possible ligand interactions and its receptor. Docking results were then visualized using BIOVIA Discovery Studio ver.19 [11]. 


\section{RESULTS AND DISCUSSIONS}

The docking results showed that lycopene has lower binding energy than quercetin with VEGFR-2. The data indicated that lycopene has a higher potential VEGFR-2 inhibitor than quercetin and a stronger binding affinity with VEGFR-2 (Table-1). Unfortunately, when VEGFA was docked with VEGFR-2-lycopene complex, the binding energy decreased. Lycopene might increase the binding affinity between VEGFR-2 and VEGF-A. Unlike lycopene, quercetin increases binding energy when VEGF-A was docked with VEGFR-2, and this showed that quercetin might decrease the binding affinity between VEGFR-2 and VEGF-A. The lower binding energy indicates that the molecule is more stable than the molecule with higher binding energy [13].

Docking between VEGFR-2 and VEGFA as natural ligands showed 18 amino acid residues consisting of eight hydrogen bonds, three hydrophobic bonds, three electrostatic bonds, and four unfavorable bumps. Hydrogen bonds are a type of strong bond and stronger than hydrophobic and electrostatic bonds. Hydrogen bonds have a high affinity with electrons so that two atoms or different molecules can bind with each other [15]. However, the stability of VEGFR-2 with VEGFA might be affected by 4 unfavorable bumps. Interactions between VEGFR-2 and VEGFA are defined as VEGFR-2 active site.

Lycopene and quercetin that interacted with VEGFA proved a change of interactions between VEGFR-2 and VEGFA. The docking results of VEGFR-2 with lycopene and VEGFA showed 17 amino acid residues interactions that consist of 7 hydrogen bonds, four hydrophobic bonds, an electrostatic bond, and five unfavorable bumps. The presence of lycopene showed a change of binding site between VEGFA and VEGFR-2 in 13 out of 17 amino acid residues, and only four amino acid residues from VEGFR-2 are still binding with VEGFA, which is Tyr137, Lys286, Val219, and Asp257. Furthermore, that complex showed unfavorable bumps with Val219 and Asp257, hydrophobic bond with Tyr137, and hydrogen bond with Lys286.

The docking results of VEGFR-2 with quercetin and VEGFA showed 17 amino acid interactions that consist of a hydrogen bond, eight hydrophobic bonds, an electrostatic bond, and seven unfavorable bumps. The presence of unfavorable bumps might disturb the stability of the interactions, even though there is a change of binding location of VEGFA with VEGFR-2 with the presence of quercetin. The presence of quercetin showed a change of VEGFA binding site with VEGFR-2 in 12 out of 17 amino acid residues. Only five amino acid residues from VEGFR-2 are still binding with VEGFA, Lys286 with electrostatic bond, Tyr194 and Leu252 with hydrophobic bond, and Asn253 and Asp257 with unfavorable bumps. This also showed that the bond's strength gets weaker after quercetin binds to VEGFR-2 and VEGFA is docked afterward. The results of each bond that occurred from VEGFR-2 and ligands interaction with their binding energy is shown in Table 1.

The interaction of VEGFA with VEGFR-2 is shown in Figure 2. VEGFR2 (gray) is shown from two perspectives to view the VEGFA binding site (yellow). The VEGFA (blue) changes its position in binding with VEGFR-2 when an active compound is present in VEGFR-2. Active compounds covered the active binding site of VEGFR-2 that should be the place that VEGFA. Those data suggested that lycopene and quercetin were possibly interrupted the binding of VEGFA with VEGFR-2.

The VEGFR2-lycopene-VEGFA complex showed that the binding position of VEGFA has a different position than before due to the presence of lycopene (red). Then there is the active site of VEGFR2, which is not covered by VEGFA and changes in VEGFA interaction with VEGFR-2 amino acid (Table 1). Quercetin also changes the binding site of VEGFR2-VEGFA when quercetin interacted with VEGFR2 (Table 1). Both lycopene and quercetin interrupted Val 218 and Val 219 of VEGFR-2 protein and might inhibit VEGFAVEGFR-2.

Lycopene and quercetin effects on angiogenesis and predicted as a non-competitive inhibitory mechanism. Those compounds bound to non-active sites of VEGFR-2 protein (Table 1). The Val 217, Val 218, and Val 219 residues are active sites of VEGFA-VEGFR-2. after docking with VEGFA. When that amino acid binds with VEGFA, the binding affinity is increased and VEGFR-2 activated. However, interrupted amino acid decreased the binding affinity and disturbed VEGFR-2 [16]. Lycopene bound to the active site of VEGFR-2, while not for quercetin (Table 1). Hence, this phenomenon showed that lycopene and quercetin are potentially inhibited transduction signals for the angiogenesis mechanism through blocking VEGFA-VEGFR2.

The VEGFR-2 structure consists of seven domains, including extracellular regions composed of immunoglobulins (Ig)-like domain. The intracellular region of VEGFR-2 is a tyrosine kinase domain. VEGF-A binds to the second and third extracellular Ig-like domains of VEGFR-2. Ligand binding induces dimerization of the receptor and autophosphorylation. The VEGF ligand binding to domains 2 and 3 of a monomer 
receptor increases the probability that the second receptor monomer binds the already bound ligand. Once two receptors are cross-linked with each other, by simultaneous interaction with the ligand, the domain 7s of Ig-like domain are held close so low-affinity homotypic interactions between domains can stabilize the receptor dimers [17].

Table 1. Types of bonds occurred between ligands and VEGFR-2 and binding energy.

\begin{tabular}{|c|c|c|c|c|c|}
\hline Interaction & Name & $\begin{array}{l}\text { Distance } \\
\text { (̊) }\end{array}$ & Category & Type & $\begin{array}{c}\text { Energy } \\
(\mathrm{kcal} / \mathrm{mol})\end{array}$ \\
\hline \multirow{7}{*}{ Lycopene } & :LIG1:C - R:PRO166 & 3.69183 & Hydrophobic & Alkyl & \multirow{7}{*}{-332.00} \\
\hline & :LIG1:C - R:PRO166 & 5.40581 & Hydrophobic & Alkyl & \\
\hline & :LIG1:C - R:ARG222 & 3.89126 & Hydrophobic & Alkyl & \\
\hline & :LIG1:C - R:LEU252 & 3.91698 & Hydrophobic & Alkyl & \\
\hline & :LIG1:C - R:VAL218 & 3.89939 & Hydrophobic & Alkyl & \\
\hline & R:TYR194 - :LIG1:C & 4.93703 & Hydrophobic & Pi-Alkyl & \\
\hline & R:TYR224 - :LIG1:C & 4.54714 & Hydrophobic & Pi-Alkyl & \\
\hline \multirow{5}{*}{ Quercetin } & :LIG1:H - :LIG1:O & 2.21606 & $\begin{array}{l}\text { Hydrogen } \\
\text { bond }\end{array}$ & $\begin{array}{l}\text { Conventional } \\
\text { Hydrogen Bond }\end{array}$ & \multirow{5}{*}{-169.34} \\
\hline & R:MET213:CE - :LIG1 & 2.69938 & Hydrophobic & Pi-Sigma & \\
\hline & R:MET213:CE - :LIG1 & 3.52632 & Hydrophobic & Pi-Sigma & \\
\hline & R:MET213:SD - :LIG1 & 4.16524 & Other & Pi-Sulfur & \\
\hline & :LIG1 - R:ARG164 & 4.949 & Hydrophobic & Pi-Alkyl & \\
\hline \multirow{18}{*}{$\begin{array}{l}\text { VEGFR 2- } \\
\text { VEGFA }\end{array}$} & A:TYR39:HH - R:VAL216:O & 2.70901 & $\begin{array}{l}\text { Hydrogen } \\
\text { Bond }\end{array}$ & $\begin{array}{l}\text { Conventional } \\
\text { Hydrogen Bond }\end{array}$ & \multirow{18}{*}{-702.02} \\
\hline & R:VAL218:HN - A:GLU38:O & 2.14529 & $\begin{array}{l}\text { Hydrogen } \\
\text { Bond }\end{array}$ & $\begin{array}{l}\text { Conventional } \\
\text { Hydrogen Bond }\end{array}$ & \\
\hline & A:GLN37:HE22 - R:GLU251:O & 2.43555 & $\begin{array}{l}\text { Hydrogen } \\
\text { Bond }\end{array}$ & $\begin{array}{l}\text { Conventional } \\
\text { Hydrogen Bond }\end{array}$ & \\
\hline & $\begin{array}{l}\text { A:PRO40:CD - } \\
\text { R:ASN253:OD1 }\end{array}$ & 2.97188 & $\begin{array}{l}\text { Hydrogen } \\
\text { Bond }\end{array}$ & $\begin{array}{l}\text { Carbon Hydrogen } \\
\text { Bond }\end{array}$ & \\
\hline & $\begin{array}{l}\text { A:GLY59:HN - } \\
\text { R:ASP257:OD1 }\end{array}$ & 2.21112 & $\begin{array}{l}\text { Hydrogen } \\
\text { Bond }\end{array}$ & $\begin{array}{l}\text { Conventional } \\
\text { Hydrogen Bond }\end{array}$ & \\
\hline & $\begin{array}{l}\text { R:ASN259:HD22 - } \\
\text { A:ARG23:O }\end{array}$ & 2.49472 & $\begin{array}{l}\text { Hydrogen } \\
\text { Bond }\end{array}$ & $\begin{array}{l}\text { Conventional } \\
\text { Hydrogen Bond }\end{array}$ & \\
\hline & R:SER310:HG - A:CYS68:O & 2.60021 & $\begin{array}{l}\text { Hydrogen } \\
\text { Bond }\end{array}$ & $\begin{array}{l}\text { Conventional } \\
\text { Hydrogen Bond }\end{array}$ & \\
\hline & R:GLY312:HN - A:CYS57:O & 2.95978 & $\begin{array}{l}\text { Hydrogen } \\
\text { Bond }\end{array}$ & $\begin{array}{l}\text { Conventional } \\
\text { Hydrogen Bond }\end{array}$ & \\
\hline & R:VAL219 - A:LEU97 & 5.28446 & Hydrophobic & Alkyl & \\
\hline & R:ALA308 - A:CYS60 & 4.1724 & Hydrophobic & Alkyl & \\
\hline & A:VAL69 - R:LEU313 & 5.25991 & Hydrophobic & Alkyl & \\
\hline & A:GLU73:OE1 - R:TYR137 & 4.62267 & Electrostatic & Pi-Anion & \\
\hline & R:GLU261:OE2 - A:TYR21 & 4.89442 & Electrostatic & Pi-Anion & \\
\hline & R:LYS286 - A:ASP34:OD2 & 4.83518 & Electrostatic & Attractive Charge & \\
\hline & R:SER193:O - A:ASP41:OD2 & 1.88992 & Unfavorable & Unfavorable Bump & \\
\hline & R:TYR194:CA - A:ASP41:CB & 2.067 & Unfavorable & Unfavorable Bump & \\
\hline & R:LEU252:C - A:GLN37:NE2 & 2.10494 & Unfavorable & Unfavorable Bump & \\
\hline & R:VAL254:N - A:GLN37:NE2 & 1.49651 & Unfavorable & Unfavorable Bump & \\
\hline
\end{tabular}


Table 1. Continued

\begin{tabular}{|c|c|c|c|c|c|}
\hline Interaction & Name & $\begin{array}{l}\text { Distance } \\
\text { (§) }\end{array}$ & Category & Type & $\begin{array}{c}\text { Energy } \\
(\text { kcal } / \text { mol })\end{array}$ \\
\hline \multirow{17}{*}{$\begin{array}{l}\text { VEGFR2 - } \\
\text { Lycopene - } \\
\text { VEGFA }\end{array}$} & $\begin{array}{l}\text { R:HIS133:HD1 - } \\
\text { A:GLU42:OE2 }\end{array}$ & 3.08062 & $\begin{array}{l}\text { Hydrogen } \\
\text { Bond }\end{array}$ & $\begin{array}{l}\text { Conventional } \\
\text { Hydrogen Bond }\end{array}$ & \multirow{17}{*}{-707.07} \\
\hline & A:SER74:HG - R:VAL254:O & 2.63464 & $\begin{array}{l}\text { Hydrogen } \\
\text { Bond }\end{array}$ & $\begin{array}{l}\text { Conventional } \\
\text { Hydrogen Bond }\end{array}$ & \\
\hline & $\begin{array}{l}\text { R:ILE256:HN - } \\
\text { A:GLN98:OE1 }\end{array}$ & 2.70618 & $\begin{array}{l}\text { Hydrogen } \\
\text { Bond }\end{array}$ & $\begin{array}{l}\text { Conventional } \\
\text { Hydrogen Bond }\end{array}$ & \\
\hline & $\begin{array}{l}\text { R:ASN274:HD22 - } \\
\text { A:PRO28:O }\end{array}$ & 1.62579 & $\begin{array}{l}\text { Hydrogen } \\
\text { Bond }\end{array}$ & $\begin{array}{l}\text { Conventional } \\
\text { Hydrogen Bond }\end{array}$ & \\
\hline & $\begin{array}{l}\text { R:LEU277:HN - } \\
\text { A:GLU72:OE1 }\end{array}$ & 2.28398 & $\begin{array}{l}\text { Hydrogen } \\
\text { Bond }\end{array}$ & $\begin{array}{l}\text { Conventional } \\
\text { Hydrogen Bond }\end{array}$ & \\
\hline & R:LYS286:HZ1 - A:GLU73:O & 2.75082 & $\begin{array}{l}\text { Hydrogen } \\
\text { Bond }\end{array}$ & $\begin{array}{l}\text { Conventional } \\
\text { Hydrogen Bond }\end{array}$ & \\
\hline & $\begin{array}{l}\text { R:THR293:HN - } \\
\text { A:GLN22:OE1 }\end{array}$ & 2.04705 & $\begin{array}{l}\text { Hydrogen } \\
\text { Bond }\end{array}$ & $\begin{array}{l}\text { Conventional } \\
\text { Hydrogen Bond }\end{array}$ & \\
\hline & A:TYR39 - R:VAL135 & 4.62732 & Hydrophobic & Pi-Alkyl & \\
\hline & R:TYR137 - A:MET94 & 5.37546 & Hydrophobic & Pi-Alkyl & \\
\hline & R:VAL273:CG2 - A:HIS27 & 3.5305 & Hydrophobic & Pi-Sigma & \\
\hline & R:ARG275 - A:LYS101 & 3.55749 & Hydrophobic & Alkyl & \\
\hline & R:GLN132:N - A:ASP41:OD1 & 2.85059 & Electrostatic & Attractive Charge & \\
\hline & $\begin{array}{l}\text { R:VAL219:CG2 - } \\
\text { A:THR77:OG1 }\end{array}$ & 2.17032 & Unfavorable & Unfavorable Bump & \\
\hline & $\begin{array}{l}\text { R:ASP257:OD1 - } \\
\text { A:GLU30:OE2 }\end{array}$ & 5.08976 & Unfavorable & $\begin{array}{l}\text { Unfavorable } \\
\text { Negative-Negative }\end{array}$ & \\
\hline & R:LEU272:N - A:GLN22:OE1 & 1.98483 & Unfavorable & $\begin{array}{l}\text { Unfavorable } \\
\text { Bump;Unfavorable } \\
\text { Acceptor-Acceptor }\end{array}$ & \\
\hline & $\begin{array}{l}\text { R:ASP276:CB - } \\
\text { A:GLU72:OE1 }\end{array}$ & 1.69256 & Unfavorable & Unfavorable Bump & \\
\hline & $\begin{array}{l}\text { R:PHE288:CE2 - } \\
\text { A:ASN100:ND2 }\end{array}$ & 2.11485 & Unfavorable & Unfavorable Bump & \\
\hline \multirow{11}{*}{$\begin{array}{l}\text { VEGFR2 - } \\
\text { QUERCET } \\
\text { IN- VEGFA }\end{array}$} & R:GLY255:CA - A:GLN37:O & 2.4339 & $\begin{array}{l}\text { Hydrogen } \\
\text { Bond }\end{array}$ & $\begin{array}{l}\text { Carbon Hydrogen } \\
\text { Bond }\end{array}$ & \multirow{11}{*}{-679.17} \\
\hline & R:PRO166 - A:ILE29 & 5.08043 & Hydrophobic & Alkyl & \\
\hline & R:PHE170 - A:VAL20 & 4.81096 & Hydrophobic & Pi-Alkyl & \\
\hline & R:VAL171 - A:VAL14 & 5.12477 & Hydrophobic & Alkyl & \\
\hline & A:CYS60 - R:MET191 & 4.68886 & Hydrophobic & Alkyl & \\
\hline & R:TYR194 - A:ILE29 & 4.67605 & Hydrophobic & Pi-Alkyl & \\
\hline & A:PRO70 - R:LEU252 & 5.27598 & Hydrophobic & Alkyl & \\
\hline & A:PRO40 - R:ILE256 & 4.24375 & Hydrophobic & Alkyl & \\
\hline & R:PHE288 - A:PRO40 & 5.29418 & Hydrophobic & Pi-Alkyl & \\
\hline & $\begin{array}{l}\text { R:LYS286:NZ - } \\
\text { A:GLU38:OE2 }\end{array}$ & 2.53492 & Electrostatic & Attractive Charge & \\
\hline & R:TYR165:O - A:ILE29:CD1 & 2.21094 & Unfavorable & Unfavorable Bump & \\
\hline
\end{tabular}


Table 1. Continued

\begin{tabular}{|c|c|c|c|c|c|}
\hline Interaction & Name & $\begin{array}{l}\text { Distance } \\
\text { (A) }\end{array}$ & Category & Type & $\begin{array}{l}\text { Energy } \\
(\text { kcal/mol) }\end{array}$ \\
\hline \multirow{6}{*}{$\begin{array}{l}\text { VEGFR2 - } \\
\text { QUERCET } \\
\text { IN- VEGFA }\end{array}$} & $\begin{array}{l}\text { R:LYS168:CG - } \\
\text { A:ARG23:CB }\end{array}$ & 2.2014 & Unfavorable & Unfavorable Bump & \multirow{6}{*}{-679.17} \\
\hline & $\begin{array}{l}\text { R:ARG169:CB - } \\
\text { A:VAL15:CG2 }\end{array}$ & 2.33676 & Unfavorable & Unfavorable Bump & \\
\hline & $\begin{array}{l}\text { R:TYR190:CD1 - } \\
\text { A:CYS60:CB }\end{array}$ & 2.18968 & Unfavorable & Unfavorable Bump & \\
\hline & R:ASN253:O - A:GLN37:NE2 & 2.05063 & Unfavorable & Unfavorable Bump & \\
\hline & $\begin{array}{l}\text { R:ASP257:OD2 - } \\
\text { A:ASP41:OD1 }\end{array}$ & 4.87371 & Unfavorable & $\begin{array}{l}\text { Unfavorable } \\
\text { Negative-Negative }\end{array}$ & \\
\hline & $\begin{array}{l}\text { R:PHE258:CB - } \\
\text { A:ASP41:OD1 }\end{array}$ & 1.78168 & Unfavorable & Unfavorable Bump & \\
\hline
\end{tabular}

\section{VEGFR2 - Lycopene}

A
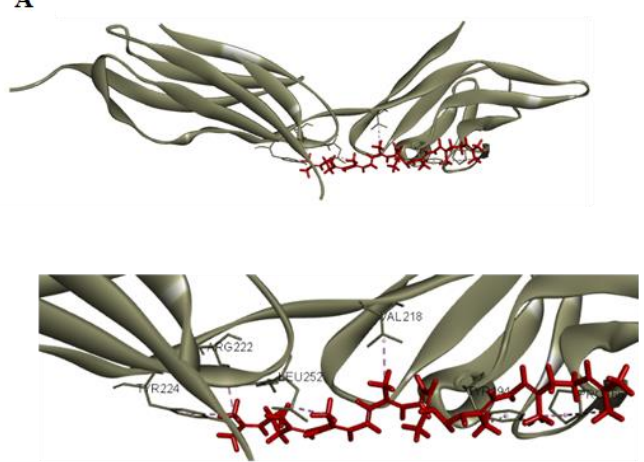

YAL218

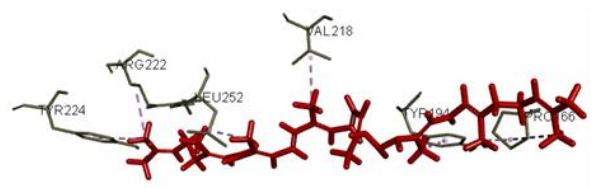

VEGFR2 - Quercetin
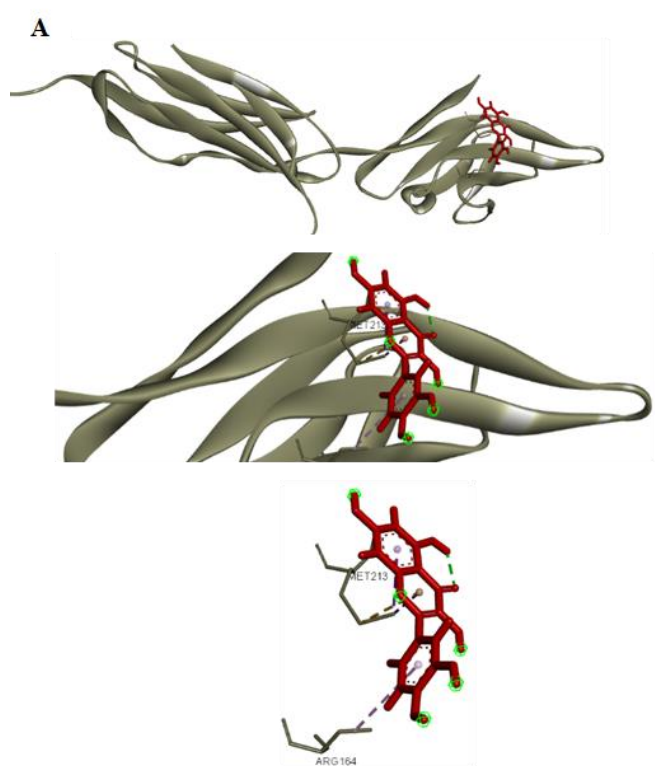

B

B

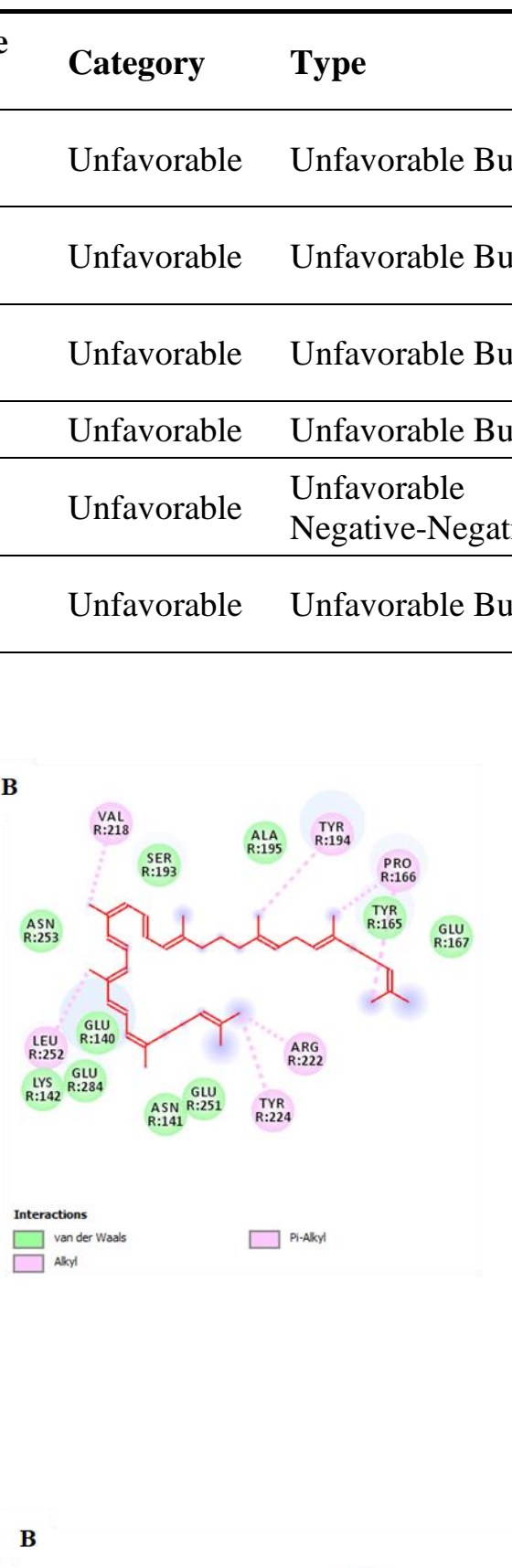

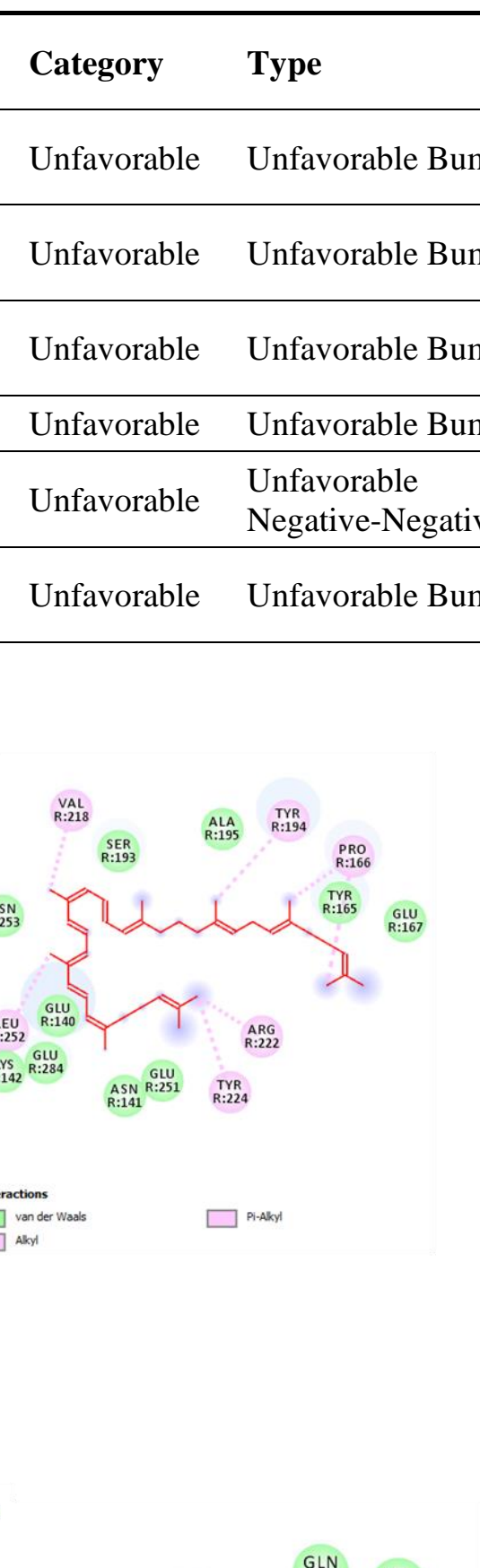

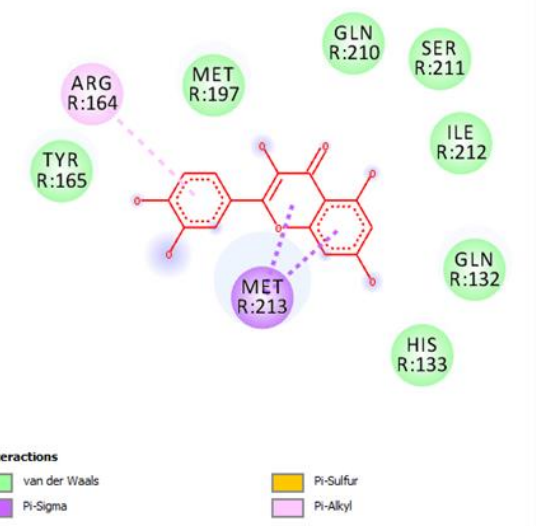

Figure 1. VEGFR-2 binding with lycopene and quercetin: (A) binding location and ligand interaction; (B) 2D diagram ligand interaction. 
VEGFR-2 mediates several physiological and pathological effects of VEGF-A on endothelial cells, such as proliferation, migration, survival, and permeability [17]. The binding of VEGF-A to VEGFR-2 induces proliferation by activation of the extracellular signal-regulated kinases (Erk) pathway. VEGFR-2 stimulates Erk phosphorylation and proliferation by a PKCdependent pathway that involves the activation of PLC- $\gamma$. Meanwhile, on the migration pathway, the binding of VEGF-A with VEGFR-2 mediates cytoskeletal reorganization, migration, and activation of phosphoinositide 3-kinase (PI3K). The activation of PI3K regulates cellular migration by several different growth factors. In the cell survival point of view, activation of PI3K with the generation of membrane-bound $\mathrm{PIP}_{3}$ results in the membrane targeting and

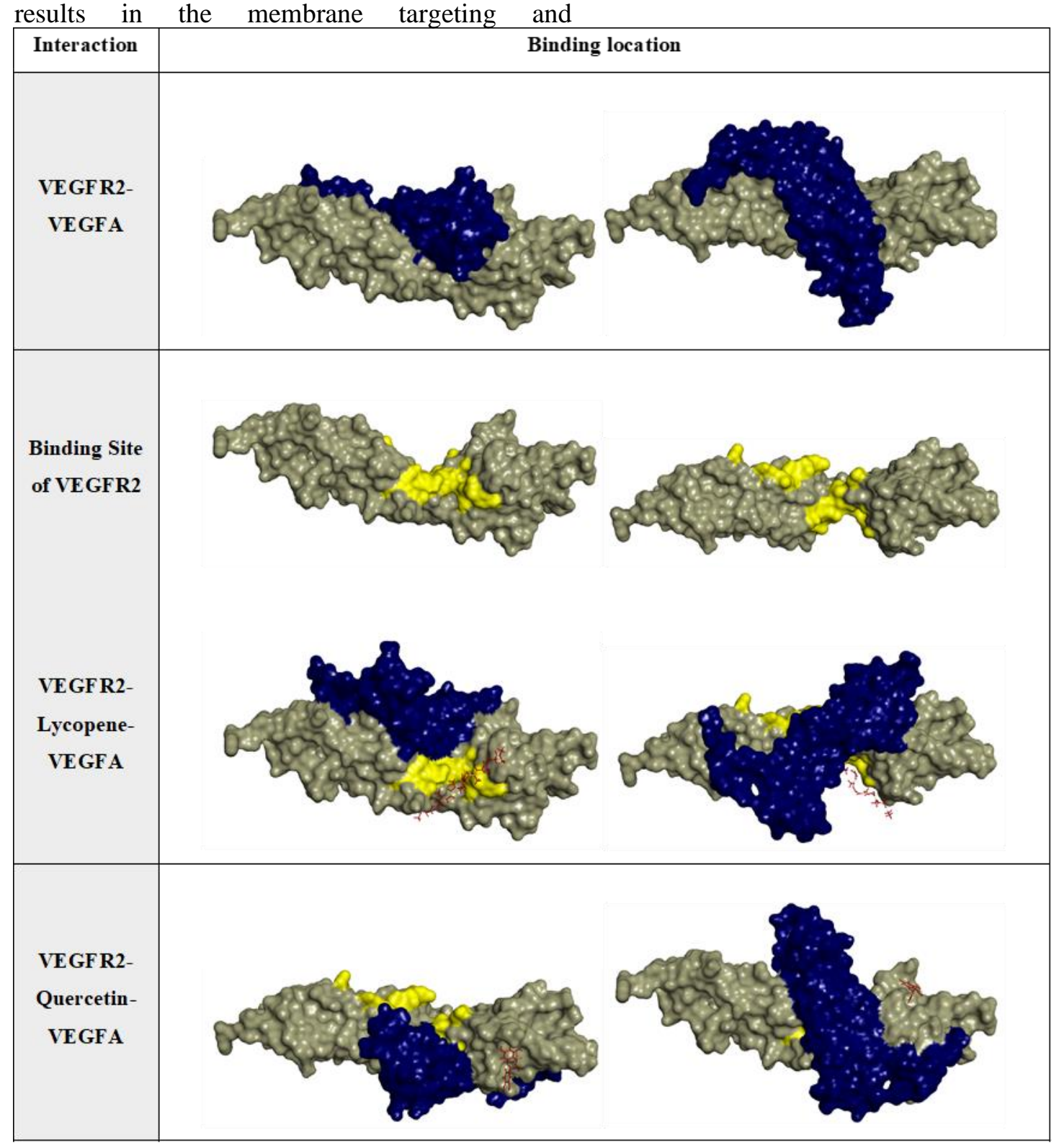

Figure 2. Binding location and interaction VEGFR2 with VEGFA phosphorylation of protein kinase $\mathrm{B}$ (PKB/Akt) and phosphoinositide-dependent kinases 1 and 2 (PDK1 and PDK2). VEGF-A also induces the expression of anti-apoptotic proteins $\mathrm{Bcl}-2$ and A1. Moreover, VEGF-A inhibited apoptosis family members XIAP and survivin that inhibit terminal effector caspases 3 and 7 [17].

Lycopene and quercetin bind to the domain 2 and 3 of the Ig-like extracellular domains of VEGFR-2, suggesting lycopene and quercetin might inhibit receptor dimerization caused by the binding of VEGF-A to domains 2 and 3 of the Iglike extracellular domains of VEGFR-2. The inhibition of the dimerization process might inhibit the autophosphorylation mechanism and switch off any downstream pathway. 


\section{CONCLUSION}

Lycopene and quercetin have the potential to inhibit angiogenesis through the VEGFR-2 pathway. Lycopene and quercetin inhibit VEGFAVEGFR-2 interaction by blocking VEGFR2. The effect of lycopene and quercetin on VEGFR-2 was the interruption of the active binding site of VEGFA that possibly inhibit any downstream pathway and protein activations required for the angiogenesis process. Further studies are required to understand lycopene and quercetin effect on angiogenesis through the VEGFR-2 pathway by combining with other compounds to formulate an anti-angiogenic drug.

\section{ACKNOWLEDGEMENT}

We would like thank to Bioinformatics assistants and lecturers for giving us tutors and teaching us the basics of molecular docking and other bioinformatic methods.

\section{REFERENCES}

1. Kementrian Kesehatan Republik Indonesia. 2019. Hari Kanker Sedunia. www.depkes.go.id Accessed on February, 29th 2020

2. Purwoastuti, E. 2008. Pencegahan dan Deteksi Dini Kanker Payudara. Kanisius. Yogyakarta

3. Mousa, S. \& P. Davis. 2016. AntiAngiogenesis Strategies in Cancer Therapies. Academic Press. London.

4. Bielenberg, D.R. \& B.R. Zetter. 2015. The contribution of angiogenesis to the process of metastasis. Cancer Journal 21(4), 267-273.

5. Srabovic, N., Z. Mujagic, J. Mustedanagic. et. al. 2013. Vascular endothelial growth factor receptor-1 expression in breast cancer and it's correlation to vascular endothelial growth factor A. International Journal of Breast Cancer 1-6.

6. Suwanaruang, T. 2016. Analyzing lycopene content in fruits. Agriculture and Agricultural Science Procedia 11: 46-48

7. Mushtaq, M., Bushra S., Haq B. \& Muhammad A. 2014. RSM based optimized enzymeassisted extraction of antioxidant phenolics from underutilized watermelon (Citrullus lanatus Thunb.) rind. Journal of Food Science and Technology 52(8):50-56

8. Rajasekar, J., Madan K.P. \& Baskaran V. 2019. A critical review on anti-angiogenic property of phytochemicals. Journal of Nutritional Biochemistry 71: 1-15.

9. Najib, A., A. Roskiana, A. Malik \& Virsa H. 2019. Potensi Tumbuhan Kanunang (Cordia myxa L.) Sebagai Bahan Obat Anti Diabetes. Deepublish. Yogyakarta.

10.Dallakyan, N. \& A.J. Olson. 2015. SmallMollecule Library Screening by Docking with PyRx. Methods in molecular biology. 1263: 243-250.

11.Dassault Systemes BIOVIA. 2019. BIOVIA Discovery Studio 2019. https://discover.3ds.com Accesed on March, 27th 2020

12.Ritchie, D.W. 2008. Accelerating and Focusing Protein-Protein Docking Correlations Using Multi-Dimensional Rotational FFT Generating Functions. Bioinformatics. 24(17): 1865-1873.

13.Finklestein, A.V., Lobanov M.Y., Dovidchenko, N.V., Bogatyreva, N.S. 2008. Many atom-Van der Waals interactions lead to direction sensitive-sensitive interactions of covalent bonds. J. Bioinform. Comput. Biol. 6(4), 693-707..

14.Safitri, E.H., J.F. Ramadhan \& S. Najihah. 2019. Comparison of virtual analysis of diosgenin and tigogenin which has potential down-regulating androgen signaling. Journal of Smart Bioprospecting and Technology 1(1):21-24

15.Puspaningtyas, A.R. 2013. Docking molekul dengan metode Molegro Virtual Docker dari ekstrak air Psidium guajava, Linn. dan Citrus sinensis, Peels sebagai inhibitor pada tirosinase untuk pemutih kulit. JKTI 15(1): 31-39.

16.Leppanen, V.M., A.E. Prota, M. Jeltsch, A. Anisimov, N. Kalkkinen, T. Strandin, H. Lankinen, A. Goldman, K.B. Hofer, K. Alitalo. 2010. Structural determinants of growth factor binding and specificity by VEGF receptor 2 . Proc Natl Acad Sci USA. 107(6):2425-2430.

17.Holmes, K., O.L. Roberts, A.M. Thomas \& M.J. Cross. 2007. Vascular endothelial growth factor receptor-2: structure, function, intracellular signalling and therapeutic inhibition. Cellular Signaling 19: 2003-2012. 